\title{
第15回 群馬脳腫痬研究会記録
}

\author{
日時: 平成 7 年 1 月 14 日(土) \\ 会場 : マーキュリーホテル \\ 会長 : 大江千廣（群馬大学脳神経外科）
}

第 1 部：診断，治療上興味ある症例

\section{座長 半田一郎（国立高崎病院）}

\section{1．乳児後頭蓋窩上衣腫の一例}

\section{嶋口 英俊, 村田 英紀, 坐間 朗 \\ 田村 勝 (群馬大学脳神経外科)}

症 例 11力月男児.

主 訴 意識障害, 呼吸障害.

現病歴 平成 5 年11月 24 日満期正常分娩にて出 生. 平成 6 年 10 月上旬より体幹失調, 10 月下旬から 発熱，嘔吐が出現した。11月 1 日自発開眼あるも， 反応なく，不規則性呼吸出現した。近医にて水頭症 に対し脳室ドレナージ術施行後, 11 月 2 日入院した。

入院時 不規則性呼吸, 軽度左片麻痺, 眼球下転, 水平性眼振, 両側角膜反射消失を認めた。 11月 7 日 VP シャント術, 気管切開術施行. 11月14日第四脳室

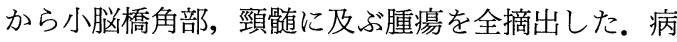
理診断は上衣種であった。術後に施行した MRI で は enhance される mass を認めず，11月28日および 平成 7 年 1 月 12 日 CBDCA $120 \mathrm{mg}, \mathrm{MCNU} 35 \mathrm{mg}$ にて化学療法を施行した。現在全身状態良好，神経 学的にも改善を認めている.

乳幼児の上衣腫の治療方針は(1)全摘を心がける， (2)化学療法 CBDCA，MCNU および vincristine, cyclophosphamide 2 コースづつ交互に行う。(3) 放射線療法は乳児という特性を考えて施行しないか 3 歳まで待って行うか再発時には 3 歳以下でも行う 等検討中である.

\section{Macrocystic trigeminal schwannoma の一例}

\section{豊田収（中央群馬脳神経外科病院）}

症 例 51歳, 男.

主 訴 眩暈と顔面違和感。1994年 3 月より症状 出現し, 同年 6 月 22 日当院紹介入院とんなった.
入院時所見 意識清明で，平衡障害あり，右顔面 の張る様な違和感あり。血液生化学検査にて OGTT にて DM pattern を呈していた以外異常所見なし. CT にて左小脳橋角部に周辺が僅か enhance される 低吸収病巣あり, MRI にては T1 で low, T2 で high intensity, Gdにて ring-like に enhanceされる mass lesion を認めた。脳血管撮影では特に腫場血管 認めず．同年 7 月 4 日腫瘍摘出術施行し，左三叉神 経より発生したと思われる macrocystic schwannoma を摘出した. 術後症状は改善した.

頭蓋内 macrocystic schwannoma は希な腫瘍で あり, trigeminal nerveより発生した例は更に希で ある。

\section{3. 眼窩内神経鞘腫の一例}

清水 常正, 門脇 弘孝, 武田 直人 （伊勢崎佐波医師会病院脳神経外科）

\section{久保 長生}

（東京女子医科大学脳神経外科）

三叉神経第一枝より発生した眼窩内神経鞘腫の一 例を経験したので報告する。

47歳，男性. 平成 5 年 4 月右視力障害に気付く. その後右眼球突出, 視野障害が出現し, 平成 6 年 9 月入院した. 頭蓋骨 X-Pにて上眼窩裂の拡大あり. MRI 等にて眼球の上後部から上眼窩裂におよぶ腫 激像が見られた. 右前頭開頭にて全摘術を施行した。 被膜をもつ extraconus の腫瘍であり, 病理は神経 鞘腫であった。術後, 視力と視野は急速に改善した が, 三叉神経第一枝の領域の知覚消失がみられた。 術中所見ともあわせこの神経が発生母地と考えられ た。 


\section{4. 脳悪性リンパ腫の 2 例 \\ 山口 純一, 清水 庸夫}

(関東脳神経外科病院)

最近経験した脳悪性リンパ腫の 2 例について報告 した。

1 例目は52歳, 女性. Diplopia にて発症. 前医で whole brain irradiation 54.6Gy を受けて寛解. 8 カ月後に再発したがステロイドのみで tumor は消 失. 3 年 1 力月後に左片麻痺出現し, 当院搬入. rt. MC occlusion による rt. temporo-parietal region の infarctionの診断で加療したが severe disability. 3 年 4 力月後に tumor の脳室内播種を起こし 3 年 6 力月後に死亡した.

2 例目は64歳, 女性. 大腸ポリポージスの既往あ り.頭痛, 左片麻痺で発症. CT, MRI で rt.parietal lobe, rt. thalamus に各 $3 \times 2 \times 2.5 \mathrm{~cm}$, 径 $1.5 \mathrm{~cm}$ の enhanced mass あり. ステロイド 1 クール後に, rt. parietal mass のみ亜全摘した. histology は diffuse large cell type, B cell type であった. ステロイド 2 クール目後に全脳38Gy+局所12Gy の irradiation 施行し, tumor は消失. 現在 no deficit で外来 follow 中である.

\section{5. 脳梗塞との鑑別に $1 \mathrm{H}-\mathrm{MRS}$ Chemical Shift} Imaging (CSI) が有用であった悪性 glioma の一 例

\section{杉田 正夫, 西松 輝高, 池田 佳生} (沼田脳神経外科循環器科病院)

【症例】64歳男性, 3 日間に進行性意識障害, 右片 麻痺を主訴に入院. 既往歴に高血圧, 脳梗塞がある. 入院時, 意識は I - 2 , 右弛緩性片麻痺と視覚失認を 認めた。 入院時 MRIにて急性期と陳旧性病巣が混 在する多発性脳梗塞と診断し脳梗塞に対する治療に て一時的に改善したが, 脳梗塞の経過を見るために 1 H-MRS-CSI を行ったところ, 左後頭葉内側面で コリン, 乳酸信号が高值, NAA 低值を示したため腫 瘍性病変と考光治療方針を変更し, 定位的生検術を 施行, glioblastoma であった. パラプラチン投与, 照射にも反応せず死亡した。

【考察】glioma 系脳腫㿟の MRS はコリン, 乳酸が 高値, MAA が低值を示す. MRS-CSI は測定範囲 peak の信号強度により画像化したもので, 代謝状態 を視覚的に認識できる利点がある. 脳腫演と脳梗塞 の鑑別には大きな診断根拠を提供しうるものと考え
る.

\section{6. 頭蓋内原発小児 spindle cell sarcoma の一例 石内 勝吾, 宮崎 瑞穂, 中村 正 斎藤 太, 橋場 康弘}

（前橋赤十字病院脳神経外科）

\section{症 例 1 歳 6 力月男児.}

頭蓋内圧方進症状と顔面を含む右半身麻痺を主訴 に当科に紹介入院となった. MRI 上, 右前頭葉に多 房性の巨大な囊胞成分を含む腫湯を認めた。術中所 見上，硬膜に著変なく，脳表は赤色調で血管に富ん でいた。琥珀色の囊胞内溶液を約 $30 \mathrm{ml}$ 吸引した。腫 瘍は灰白色弾性軟で, 腫瘍腔底面を除いて境界が認 められた。肉眼的に全摘後, CBDCA およびVP-16 による化学療法を行い, 術後麻舫は消失し, 現在 CR が 7 カ月続いている.

摘出腫瘍は紡鍾型細胞が主体を成し, 線維束状の 配列を示す。免疫組織学的にはvimentin および actin が陽性だが，グリア系および神経系マーカー は陰性である。電顕上良く発達した Golgi 装置と粗 面小胞体および細胞外腔コラゲン線維を認め, 未分 化間葉系由来の腫瘍と考えられた。

第 2 部：Glioma の照射化学療法の検討

\section{座長 豊田 収 (中央群馬脳神経外科病院)}

\section{特別講演}

\section{座長 大江千廣（群馬大学脳神経外科）}

\section{頭蓋内悪性リンパ腫について}

\section{久保 長生}

\section{(東京女子医科大学脳神経外科)}

頭蓋内悪性リンパ腫は全脳腫瘍の $1 \%$ 前後であ る.その発生頻度が増加している。予後不良の腫崵 でありその病態解明が待たれる。われわれは1970年 から1993年までに36例の頭蓋内悪性リンパ腫を経験 したのでその臨床および病理像について検討した。 この36例はいずれも頭蓋内初発例であり臨床検査ま たは病理解剖などで原発巣が見られなかった症例の 
みである。1970-1980年は 9例で1981-1993年では

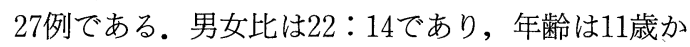
ら77歳まで平均51歳である. 多発性病変は13例であ る. 部位別ではテント上 27 例, テント下 8 例, テン 卜上下は 1 例みられた。前頭葉 6 例, 側頭葉 4 例, 頭頂葉 4 例, 後頭葉 2 例, 傍脳室基底核部 9 例であ る. 組織学的には LSG 分類で diffuse medium 11 例, diffuse large 10例, diffuse mixed 7 例, pleomorphic 3 例, lymphoblastic 2 例, diffuse small 2 例, follicular large cell 1 例であり, 全例 B cell type である. 予後の検討では第一回手術日を 観察開始日とした。観察期間は 8 力月から 9 年であ
る. 平均生存期間は 43 力月で， 1 年生存率は $53 \%$, 2 年生存率は $38 \%, 5$ 年生存率は $30 \%$ であった。手 術方法と予後との相関は見られない. 放射線照射と 化学療法を施行し得た症例が予後が良好である。と くに40Gy 以上の照射療法と CHOP 療法施行例は 予後良好である. PCNA による陽性率と予後を検討 したところ平均約 $30 \%$ であ，30\%以上で予後不良 である.腫瘍組織内に GFAP 陽性細胞が見られる症 例は比較的予後良好である. 悪性リンパ腫は今後さ らに増大すると考える. 予後に関しては組織診断と 放射線化学療法は極めて重要であり, それぞれの症 例にあった補助療法を行うべきである。 